\title{
Case Report: Genetic analysis and anesthetic management of a child with Niemann-Pick disease Type A [version 1; peer
}

\section{review: 2 approved]}

\author{
Priti G. Dalal ${ }^{1}$, Melissa Coleman ${ }^{1}$, Meagan Horst ${ }^{1}$, Dorothy Rocourt ${ }^{2}$, \\ Roger L. Ladda3, Piotr K. Janicki3
}

${ }^{1}$ Department of Anesthesiology, Penn State Hershey Medical Center, Penn State Hershey Children's Hospital, Hershey, PA, 17033, USA

2Department of Surgery, Division of Pediatric Surgery, Penn State Hershey Children's Hospital, Hershey, PA, 17033, USA

${ }^{3}$ Department of Pediatrics, Department of Pediatrics, Division of Human Genetics, Penn State Hershey Children's Hospital, Hershey, PA, 17033, USA

\section{V1 First published: 10 Dec 2015, 4:1423 \\ https://doi.org/10.12688/f1000research.7470.1}

Latest published: $10 \mathrm{Dec} 2015, \mathbf{4 : 1 4 2 3}$

https://doi.org/10.12688/f1000research.7470.1

\section{Abstract}

A 14-month-old child, recently diagnosed with Niemann-Pick disease type A, presented for a laparoscopic placement of a gastrostomy tube under general anesthesia. The disease was confirmed and further characterized by genetic testing, which revealed evidence of the presence of two known pathogenic mutations in the SMPD1 gene, and enzyme studies showed a corresponding very low level of enzymatic activity of acidic sphingomyelinase. The anesthetic management involved strategies to manage an anticipated difficult intubation and avoid post-operative ventilation.

Keywords

Anesthesia, Niemann-Pick disease, genomic and biochemical analysis

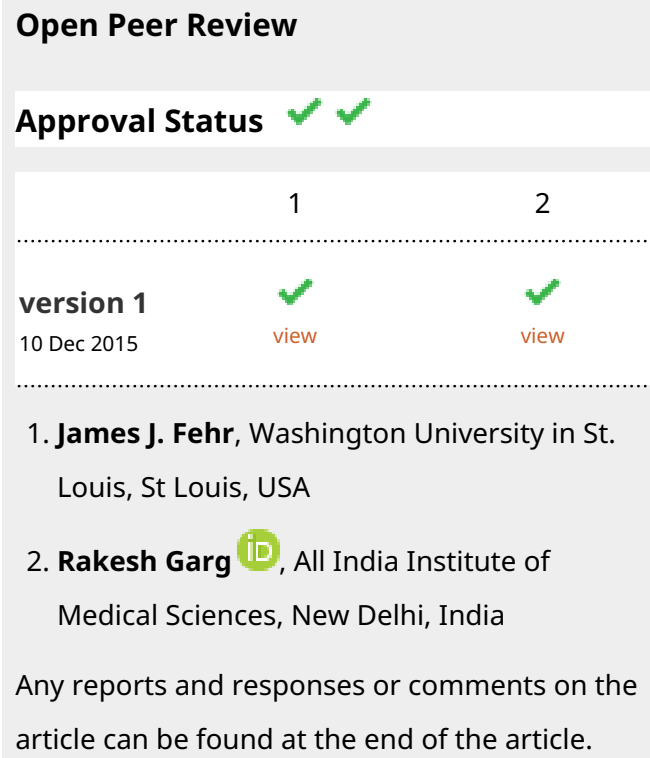

1 2 version 1 10 Dec 2015

$\checkmark$ view

1. James J. Fehr, Washington University in St. Louis, St Louis, USA

2. Rakesh Garg iD, All India Institute of Medical Sciences, New Delhi, India Any reports and responses or comments on the article can be found at the end of the article.

Corresponding author: Priti G. Dalal (pdalal@hmc.psu.edu)

Competing interests: The authors declared no competing interests.

Grant information: The author(s) declared that no grants were involved in supporting this work.

Copyright: $\odot 2015$ Dalal PG et al. This is an open access article distributed under the terms of the Creative Commons Attribution License, which permits unrestricted use, distribution, and reproduction in any medium, provided the original work is properly cited.

How to cite this article: Dalal PG, Coleman M, Horst M et al. Case Report: Genetic analysis and anesthetic management of a child with Niemann-Pick disease Type A [version 1; peer review: 2 approved] F1000Research 2015, 4:1423

https://doi.org/10.12688/f1000research.7470.1

First published: 10 Dec 2015, 4:1423 https://doi.org/10.12688/f1000research.7470.1 


\section{Introduction}

Niemann-Pick disease (NPD) is a rare inherited autosomal recessive lysosomal storage disorder (incidence about 1:40,000 in general population) caused by pathogenic mutations in the SMPD1 gene and characterised by enzyme studies showing a corresponding very low level of enzymatic activity of acidic sphingomyelinase (ASM), associated with intracellular accumulation of lipids ${ }^{1-3}$. People with NPD type A (NPA; generally a very rare presentation of NPD) have little or no ASM production (less than $1 \%$ of normal) while those with NPD type B (the most frequent presentation of NPD) have approximately $10 \%$ of the normal level of ASM. There is no information on the anesthetic management of a patient with fully genetically characterized and biochemically confirmed NPA, and only one previous report describing a pediatric patient with presumably diagnosed $\mathrm{NPA}^{4}$. In this case report, we describe the genetic background, pathophysiology and anesthetic-related problems in a patient with NPA who presented for surgery.

\section{Case report}

A 14-month-old Caucasian child (residing in the United States, diagnosed with NPA, presented to our hospital pre-anesthesia assessment clinic for laparoscopic placement of a gastrostomy tube. There was no known family member or relatives diagnosed with NPD; mother reported a distant relative of Jewish origin. On physical exam, he was a well-proportioned child, weight was $8.32 \mathrm{~kg}$ $\left(10^{\text {th }}\right.$ percentile $)$ and height was $77 \mathrm{~cm}\left(50-75^{\text {th }}\right.$ percentile $)$, head circumference was $48.3 \mathrm{~cm}\left(90-95^{\text {th }}\right.$ percentile). Craniofacial features included frontal bossing, protuberant tongue and mild bilateral ptosis. Generalized hypotonia with head lag and weakness in upper girdle and lower leg muscles, decreased deep tendon reflexes and hepatosplenomegaly ( $3 \mathrm{~cm}$ below the costal margin) were noted. Liver function tests revealed elevation of alanine transaminase (ALT) levels - 90 uts/L (normal range 13-69), aspartate transaminase (AST) levels - 271 uts/L (normal range 9-80), alkaline phosphatase levels - 252 uts/L (normal 8-240) and creatine phosphokinase (CPK) - <20 uts/L (normal range 55-170).

The child was scheduled as the first case on the day of surgery. General anesthesia was induced with a 50:50 mixture of nitrous oxide: oxygen and sevoflurane. Following a smooth inhalational induction, intravenous access was established and a single dose of propofol $2 \mathrm{mg} / \mathrm{kg}$ was administered intravenously to facilitate tracheal intubation. Tracheal intubation was performed under deep anesthesia with a $4 \mathrm{~mm}$ internal diameter cuffed endotracheal tube with a c-MAC videolaryngoscope blade (Cormack and Lehane grade 2 view, Figure 1). Anesthesia was maintained with air: oxygen and sevoflurane mixture (Minimum Alveolar Concentration i.e. $\mathrm{MAC}=1$ ). A single dose of per rectal acetaminophen $240 \mathrm{mg}$ (30-40 mg/kg) and local anesthetic infiltration with $0.25 \%$ bupivacaine were used to facilitate analgesia. Tracheal extubation was uneventful. The child was transported to the post-anesthesia care unit and made an uneventful post-operative recovery.

Follow-up The child had G-tube feeds commenced following surgery and subsequently discharged to home the following day and made an uneventful clinical recovery. Subsequently over the course of next few months, the child had episodes of intractable seizures which were medically managed. The patient was referred to home hospice care and expired at home at the age of 2 years.

\section{Biochemical evaluation}

The results of enzymatic evaluation of patient blood and leukocytes by an outside laboratory are presented in Table 1.

\section{Genetic evaluation}

Extracted DNA was PCR-amplified for analysis of the coding exons 1 to 6 of the SPMD1 gene and their flanking splice sites, using a standard Sanger sequencing approach. Bi-directional sequence was obtained and the DNA sequence was analyzed and compared to the published gene sequence. Reportable variants were confirmed by repeat sequence analysis. Based on the genetic diagnostic laboratory (Proprietary information from GeneDx, Gaithersburg, MD) 99\% sensitivity is expected in detecting mutations identifiable by sequencing. Please refer to Table 2.

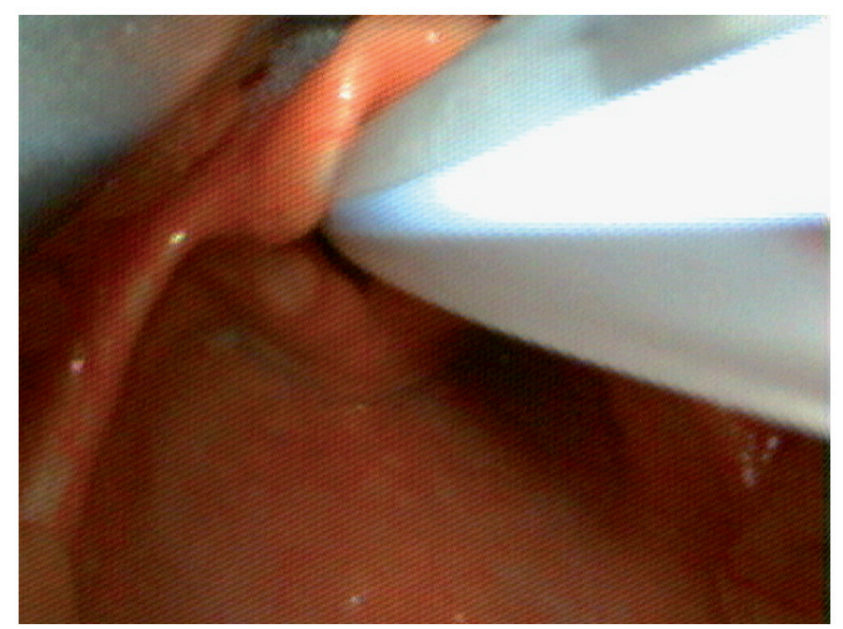

Figure 1. Laryngeal view at intubation with the videolaryngoscope.

Table 1. Biochemical enzymatic pattern of investigated patient (by Lysosomal Diseases Testing Laboratory, Philadelphia, PA).

\begin{tabular}{|l|l|l|l|}
\hline Enzyme & $\begin{array}{l}\text { Tissue } \\
\text { source }\end{array}$ & $\begin{array}{l}\text { Results } \\
\text { (nmol/hr/mg } \\
\text { protein) }\end{array}$ & Comments \\
\hline Beta-galactosidase & L/P & $62.5 / 17.7$ & Normal range \\
\hline Beta-mannosidase & $\mathrm{L}$ & 100.9 & Normal range \\
\hline Alpha-L-fucosidase & $\mathrm{L}$ & 52.3 & Normal range \\
\hline Alpha-mannonidase & $\mathrm{L}$ & 207.1 & Normal range \\
\hline Beta-glucuronidase & $\mathrm{L}$ & 313.6 & Normal range \\
\hline Beta-hexaminidase A & $\mathrm{L}$ & 284.0 & Normal range \\
\hline Sphingomyelinase & $\mathrm{L}$ & $\mathbf{0 . 0 6}$ & $\begin{array}{l}\text { Abnormally } \\
\text { low }\end{array}$ \\
\hline Glucorerebrosidase & $\mathrm{L}$ & 19.5 & Normal range \\
\hline Alpha-L-idorinidase & $\mathrm{L}$ & 31.8 & Normal range \\
\hline Alpha-glucosaminidase & $\mathrm{P}$ & 71.1 & Normal range \\
\hline Mucolipidoses II/III & $\mathrm{P}$ & $\mathrm{N} / \mathrm{A}$ & Ruled out \\
\hline P-Plasma, L- Leukocytes - Bold face denotes abnormal results
\end{tabular}


Table 2. The sequencing analysis provided evidence of the presence of two pathogenic mutations in the SMPD1 gene.

\begin{tabular}{|l|l|l|l|l|}
\hline Gene & cDNA & Variant & Zygosity & Classification \\
\hline SPMD1 & ${ }^{*}$ C.573delT & p.Ser192AlafsX65 & heterozygous & $\begin{array}{l}\text { Disease-causing } \\
\text { mutation }\end{array}$ \\
\hline SPMD1 & ${ }^{* *}$ C.1783_1784delCT & p.Ala597ProfsX7 & heterozygous & $\begin{array}{l}\text { Disease-causing } \\
\text { mutation }\end{array}$ \\
\hline
\end{tabular}

*The normal sequence with the base that is deleted in braces is: ACCCCC(T)AGCC. ${ }^{* *}$ The normal sequence with the bases that are deleted in braces is: TACT(CT)TTGT

\section{Discussion}

Our anesthesia management strategy focused on avoiding muscle relaxants and narcotic analgesics. Hence, endotracheal intubation under deep anesthesia without muscle paralysis and non-opioid analgesics, i.e., acetaminophen, and infiltration of the surgical wound with local anesthetic were contemplated. Adequate pain control was possible with this technique since the procedure was performed laparoscopically. Although the child had mild elevation of liver enzymes, acetaminophen was preferred as a short-term analgesic. Use of atracurium, midazolam, sevoflurane and fentanyl has been described in the management of anesthesia in a 2-year-old patient with presumable NPA presenting for emergency splenectomy ${ }^{4}$. The child had severe hepatosplenomegaly, ventilation improved after splenectomy and the child required a post-operative ICU stay for 9 days.

The observed c.573delT mutation in the SMPD1 gene in our case has been reported previously in association with NPD type $A^{5}$. The deletion causes a frame shift starting with codon Serine 192, changes this amino acid to an Alanine residue and creates a premature Stop codon at position 65 in the new reading frame denoted p.Ser192AlafsX65. This mutation is predicted to cause abnormal protein function either through protein truncation or nonsensemediated mRNA decay. The c1783_1784delCT deletion causes a frame shift starting with codon Alanine 597, changes this amino acid to a Proline residue, and creates a premature stop codon at position 7 of the new reading frame denoted p.Ala597ProfsX7. This mutation is predicted to cause loss of normal protein function through protein truncation. Specifically, the last 35 correct residues are replaced by six incorrect residues. Therefore, the presence of these mutations is consistent with the diagnosis of an SMPD1related disorder, if the mutations were inherited on different alleles (in trans), i.e., each mutation coming from a different parent ${ }^{6}$. This result therefore permits mutation-specific carrier testing for family members and prenatal diagnosis for the parents of this child, if desired. However, targeted carrier testing of both parents is necessary prior to or concurrently with any carrier testing or predictive testing in this family.

Patients with NPA and NPB have significantly different clinical course. While NPA is associated with severe neurological deficits leading to early death, patients with NPB have minimal neurological involvement and may survive to adulthood, although hepatosplenomegaly and cardiorespiratory problems may occur. We believe therefore that it is important to distinguish these form of NPD preoperatively, because NPA requires much more strict anesthetic management (avoidance of muscle relaxants and opioids, if at all possible) and it could associated more frequently with step-up level of postoperative care.

\section{Consent}

Written informed consent for publication of clinical details and/or images was obtained from the parent of the patient.

\section{Author contributions}

$\mathrm{PD}$ and PJ prepared the initial draft of the manuscript. MC, $\mathrm{MH}$, RL and DR did further literature review and modifications of the manuscript. RL gave considerable input on the genetic concepts in the manuscript. All authors have seen and agreed to the final content of the manuscript.

\section{Competing interests}

The authors declared no competing interests.

\section{Grant information}

The author(s) declared that no grants were involved in supporting this work.
1. Vanier MT: Niemann-Pick diseases. Handb Clin Neurol. 2013; 113: 1717-21. PubMed Abstract | Publisher Full Text

2. Vanier MT: Lysosomal diseases: biochemical pathways and investigations. Handb Clin Neurol. 2013; 113: 1695-9. PubMed Abstract | Publisher Full Text

3. Miao N, Lu X, O'Grady NP, et al:: Niemann-pick disease type C: implications for sedation and anesthesia for diagnostic procedures. J Child Neurol. 2012; 27(12): 1541-6.

PubMed Abstract | Publisher Full Text | Free Full Text

4. Bujok LS, Bujok G, Knapik P: Niemann-Pick disease: a rare problem in anaesthesiological practice. Paediatr Anaesth. 2002; 12(9): 806-8. PubMed Abstract | Publisher Full Text

5. Gluck I, Zeigler M, Bargal R, et al:: Niemann Pick Disease type A in Israeli Arabs: 677 delT, a common novel single mutation. Mutations in brief no. 161 . Online. Hum Mutat. 1998; 12(2): 136.

PubMed Abstract | Publisher Full Text

6. Simonaro CM, Desnick RJ, McGovern MM, et al:: The demographics and distribution of type B Niemann-Pick disease: novel mutations lead to new distribution of type B Niemann-Pick disease: novel mutations lead to new
genotype/phenotype correlations. Am J Hum Genet. 2002; 71(6): 1413-9. PubMed Abstract | Publisher Full Text | Free Full Text 


\section{Open Peer Review}

\section{Current Peer Review Status:}

\section{Version 1}

Reviewer Report 01 February 2016

https://doi.org/10.5256/f1000research.8048.r12222

(C) 2016 Garg R. This is an open access peer review report distributed under the terms of the Creative Commons Attribution License, which permits unrestricted use, distribution, and reproduction in any medium, provided the original work is properly cited.

\section{Rakesh Garg}

Department of Anaesthesiology, Pain Medicine and Critical Care, All India Institute of Medical Sciences, New Delhi, Delhi, India

Please provide more details of airway management i.e. difficulty level. Was it predicted and preparation done before inducing anaesthesia?

Please provide detail (positive or negative ) for any other additional comorbidities - structural or functional.

Please mention duration of surgery, need of any NMB drugs, other analgesia, hemodynamic status intraoperatively.

Since the title says anaesthetic management as well, It would be good if authors could add an table for various perioperative concerns in such child and their suggestions for the management.

Competing Interests: No competing interests were disclosed.

I confirm that I have read this submission and believe that I have an appropriate level of expertise to confirm that it is of an acceptable scientific standard.

Reviewer Report 01 February 2016

https://doi.org/10.5256/f1000research.8048.r11964

(C) 2016 Fehr J. This is an open access peer review report distributed under the terms of the Creative Commons Attribution License, which permits unrestricted use, distribution, and reproduction in any medium, provided the original work is properly cited.

James J. Fehr 
St Louis Children's Hospital, Washington University in St. Louis, St Louis, MO, USA

This is novel case report of a 14 month old with NPA who is undergoing an anesthetic. The manuscript is generally written, a few missing articles were noted, but the substance of the article is sound. The report is supported by appropriate references from the literature and the case description is succinct but complete. A modest improvement might be made by including the clinical presentation of NPA (what to be concerned about) in the introduction which would serve to focus the reader on the subsequent anesthetic management.

Competing Interests: No competing interests were disclosed.

I confirm that I have read this submission and believe that I have an appropriate level of expertise to confirm that it is of an acceptable scientific standard.

The benefits of publishing with F1000Research:

- Your article is published within days, with no editorial bias

- You can publish traditional articles, null/negative results, case reports, data notes and more

- The peer review process is transparent and collaborative

- Your article is indexed in PubMed after passing peer review

- Dedicated customer support at every stage

For pre-submission enquiries, contact research@f1000.com 